\title{
GABAergic and glycinergic IPSCs in Ganglion Cells of Rat Retinal Slices
}

\author{
Dario A. Protti, ${ }^{1}$ Hersch M. Gerschenfeld, ${ }^{2}$ and Isabel Llano ${ }^{1}$ \\ ${ }^{1}$ Arbeitsgruppe Zelluläre Neurobiologie, Max-Planck-Institut für biophysikalische Chemie, 37070 Göttingen, Germany, and \\ ²aboratoire de Neurobiologie, Ecole Normale Supérieure, 75005 Paris, France
}

\begin{abstract}
GABAergic and glycinergic IPSCs were studied in identified retinal ganglion cells (RGCs) of light-adapted rat retinal slices, using whole-cell recording techniques. GABAergic IPSCs were blocked specifically by SR95531 (3 $\mu \mathrm{M})$ and bicuculline $(3 \mu \mathrm{M})$ and glycinergic IPSCs by strychnine $(0.3 \mu \mathrm{M})$. From 37 RGCs studied, 25 showed exclusively GABAergic IPSCs, 6 presented only glycinergic IPSCs, and 6 showed both. This distribution may result from differences in amacrine cells input rather than from receptor heterogeneity, because both GABA and glycine elicited $\mathrm{Cl}^{-}$-selective currents in all RGCs tested. TTX markedly reduced GABAergic IPSCs frequency, whereas glycinergic IPSCs were unaffected. $\mathrm{Ca}^{2+}$-free media, with or without high $\mathrm{Mg}^{2+}$, blocked TTX-resistant GABAergic and glycinergic IPSCs. These results suggest that GABAergic IPSCs in RGCs can
\end{abstract}

be elicited either by $\mathrm{Na}^{+}$-dependent action potentials or by local $\mathrm{Ca}^{2+}$ influx in medium or large dendritic field GABAergic amacrine cells, whereas glycinergic IPSCs are generated by action potential-independent $\mathrm{Ca}^{2+}$ influx in narrow field glycinergic amacrine cells. Both types of IPSCs had fast rise times and biexponential decays, but glycinergic IPSC decay was significantly slower than that of GABAergic IPSCs. An elementary conductance of $54 \mathrm{pS}$ for the glycine-gated channels was estimated from single-channel events, clearly detected in the falling phase of glycinergic IPSCs, and from responses to exogenous glycine.

Key words: synaptic currents; GABA; glycine; retina; patchclamp; neurotransmitter receptors
Two main inhibitory neurotransmitters are involved in the organization of the receptive fields of retinal ganglion cells (RGCs): GABA and glycine (Wässle and Boycott, 1991). Both neurotransmitters are found in mammalian amacrine cells, which in their majority are presynaptic to RGCs. GABA immunoreactivity (Agardh et al., 1986; Mosinger et al., 1986; Osborne et al., 1986; Mosinger and Yazulla, 1987; Vaney and Young, 1988; Chun and Wässle, 1989; Wässle and Chun, 1989; Koontz and Hendrickson, 1990) and uptake of both $\left[{ }^{3} \mathrm{H}\right] \mathrm{GABA}$ (Pourcho, 1980) and $\left[{ }^{3} \mathrm{H}\right]$ muscimol (Pourcho, 1980; Pourcho and Goebel, 1983; Wässle et al., 1987) have been detected in amacrine cells. Glutamic acid decarboxylase (GAD), the GABA-synthesizing enzyme, was found immunocytochemically (Mosinger and Yazulla, 1987; Brecha et al., 1988) and by in situ hybridization with GAD mRNA in amacrine cells (Sarthy and Fu, 1989). Glycine accumulates in other amacrine cells of mammalian retinas (Marc and Liu, 1985), where it also was detected immunocytochemically (Hendrickson et al., 1988; Davenger et al., 1991; Pourcho and Owarczak, 1991; Koontz et al., 1993).

$\mathrm{GABA}_{\mathrm{A}}$ receptor subunits have been localized in RGCs and in the inner plexiform layer, possibly at RGC dendrites (Hughes et al., 1989, 1991; Grünert et al., 1993; Greferath et al., 1994a; Koulen et al., 1996). Glycine receptor subunits also have been found at similar sites (Pourcho and Owarczak, 1991; Grünert and

Received Feb. 26, 1997; revised May 27, 1997; accepted June 2, 1997.

This work was supported by the Max Planck Society and a von Humboldt postdoctoral fellowship to D. A. Protti. We are grateful to $\mathrm{H}$. Wässle for his advice on the preparation of retinal slices. We thank A. Marty, C. Pouzat, and H. von Gersdorff for discussions and comments on this manuscript.

Correspondence should be addressed to Dr. Isabel Llano, Arbeitsgruppe Zelluläre Neurobiologie, Max-Planck-Institut für biophysikalische Chemie, Am Fassberg, 37070, Göttingen, Germany.

Copyright (C) 1997 Society for Neuroscience $\quad 0270-6474 / 97 / 176075-\bullet \$ 05.00 / 0$
Wässle, 1993; Greferath et al., 1994b). Moreover, receptors to both transmitters are segregated spatially in clusters on the somatodendritic membranes of rat RGCs (Koulen et al., 1996).

On the basis of the effects of strychnine and bicuculline on light-evoked unitary activity of cat RGCs, Saito (1983) proposed a differential distribution of GABAergic versus glycinergic synapses in the ON versus the OFF pathways. Other work has failed to confirm these results: GABA and glycine suppressed, whereas strychnine and bicuculline enhanced, the light-evoked responses recorded from cat RGCs, regardless of their type (Bolz et al., 1985a,b). Hence, the precise role of inhibitory inputs on RGCs remains highly controversial.

More recently, GABA and/or glycine were found to induce currents in cultures of goldfish (Ishida and Cohen, 1988; Cohen et al., 1989; Ishida, 1992) and murine RGCs (Tauck et al., 1988), in isolated rat retinas (Rörig and Grantyn, 1993), and in primate retinal slices (Zhou et al., 1994). The action of both transmitters on RGCs involves a $\mathrm{Cl}^{-}$conductance increase (Tauck et al., 1988; Cohen et al., 1989). Nevertheless, with the exception of infrequent GABAergic IPSCs observed in 5-d-old rats (Rörig and Grantyn, 1993), no study has been performed on the GABAergic and glycinergic IPSCs of RGCs.

In the present work we have analyzed GABAergic and glycinergic IPSCs in RGCs of light-adapted rat retinal slices. We have found marked differences between these two classes of IPSCs concerning their time course, their distribution among the ganglion cell population studied, and their sensitivity to tetrodotoxin and removal of external $\mathrm{Ca}^{2+}$ ions. Some of these results have been reported in preliminary form (Protti et al., 1996).

\section{MATERIALS AND METHODS}

Tissue preparation. Vertical slices were prepared from the retinas of adult rats (4-7 weeks old). Animals were anesthetized deeply with Metofane 
(1.4 gm of methoxyflurane and $0.15 \mathrm{mg}$ of 2,6-di-tributyl-p-cresol per 120 $\mathrm{ml}$; Janssen GmbH, Russelsheim, Germany) and decapitated. The initial dissection followed the procedures described by Boos et al. (1993). Briefly, eyes were enucleated rapidly and transferred to a beaker filled with ice-cold physiological saline [bicarbonate-buffered saline (BBS); see Solutions and Drug Application]. After the cornea was cut along the ora serrata, lens and vitreous were removed and the retina was separated from the sclera. Then the retina was cut into four pieces with a scalpel blade, one of the fragments was embedded in $2 \%$ agar dissolved in BBS (kept at a constant temperature of $38^{\circ} \mathrm{C}$ ), and the resulting block was cooled rapidly. The block was transferred to a microslicer (Dosaka EM, Kyoto, Japan) where $200-\mu$ m-thick slices were cut. The slices were kept at $33^{\circ} \mathrm{C}$ in BBS for $1 \mathrm{hr}$ before their use for electrophysiological recording.

Electrophysiological recordings and analysis. Experiments were performed at $20-23^{\circ} \mathrm{C}$ with an upright microscope (Zeiss Axioskop, Oberkochen, Germany) equipped with Nomarski differential interference contrast optics and a water immersion objective $(63 \times, 0.9$ numerical aperture). The criteria for RGCs identification will be described in Results. The dissection, as well as the incubation and recording, was done under laboratory light conditions. Consequently, the retinal slices were light-adapted. Nevertheless, light responses were observed on some occasions. The recording chamber was perfused at a rate of $1-1.5 \mathrm{ml} / \mathrm{min}$ with BBS.

All of the experiments were performed with the tight-seal whole-cell recording (wcr) configuration of the patch-clamp technique (Hamill et al., 1981). Seal formation was achieved without previous cleaning of the neuronal surface by maintaining a moderate positive pressure in the pipette while approaching the cell. Recordings were performed with an EPC-9 amplifier and borosilicate glass pipettes having resistances of 3.5-5 M $\Omega$ when filled with $\mathrm{Cl}^{-}$-containing intracellular solution (S1; see below). Pipettes were coated with dental wax to decrease their capacitance. In wcr, capacitive currents were canceled, and series resistance compensation was applied in the range of $60-80 \%$. Only cells with uncompensated $R_{\mathrm{s}} \leq 20 \mathrm{M} \Omega$ were used in this study. The average capacitance of RGCs was $5.03 \pm 0.55 \mathrm{pF}$, and their input resistance, when dialyzed with a $\mathrm{CsCl}$ solution ( $\mathrm{S} 1$; see below), was $2.95 \pm 0.15 \mathrm{G} \Omega$ $(n=42$; mean \pm SEM $)$. Membrane potential values were corrected for liquid junction potentials.

For the study of effects of various drugs on IPSCs parameters, membrane currents were recorded in control saline for $4 \mathrm{~min}$, the bath was exchanged to the drug containing solution, and data acquisition was interrupted during 3-4 min to allow for complete equilibration of the test solution within the slice. After this period, data acquisition continued. In general, we acquired 4 min of data in each experimental condition.

Membrane currents were digitized on-line at $200 \mu \mathrm{sec} /$ point and stored in disk for subsequent analysis. Detection and analysis of IPSCs were performed with a program written by Dr. P. Vincent, as described in Vincent and Marty (1993). Unless otherwise noted, a detection threshold of 7-10 pA was used. Each detected event was inspected visually to discard from the analysis glutamatergic synaptic currents, which were characterized by a decay time constant of the order of $1 \mathrm{msec}$ (see Results). Amplitude distributions of IPSCs were constructed from the events with IGOR software (WaveMetrics, Lake Oswego, OR). Noise histograms were produced from events-free sections of the recordings; 1000 measurements of the difference in mean current between two $1 \mathrm{msec}$ segments, separated by $1.5 \mathrm{msec}$, were taken at random positions in the recording; the resulting distribution was scaled to the peak number of events of the data histogram. For the analysis of IPSCs decay, individual events were aligned at their onset, averaged, and fit by a double-exponential function. All data point histograms of singlechannel currents and the corresponding fits with gaussian functions were performed with IGOR software. Statistical values are given as the mean \pm SEM.

Solutions and drug application. The standard external solution (BBS) consisted of (in mM): $125 \mathrm{NaCl}, 2.5 \mathrm{KCl}, 2 \mathrm{CaCl}_{2}, 1 \mathrm{MgCl}_{2}, 1.25$ $\mathrm{NaH}_{2} \mathrm{PO}_{4}, 26 \mathrm{NaHCO}_{3}$, and 10 glucose (pH of 7.4 when equilibrated with a mixture of $95 \% \mathrm{O}_{2} / 5 \% \mathrm{CO}_{2}$ ). Most of the experiments were performed with an intracellular solution (S1) having a $\mathrm{Cl}^{-}$concentration close to that in the extracellular solution. Its composition was (in $\mathrm{mM}$ ): $150 \mathrm{CsCl}, 4.6 \mathrm{MgCl}_{2}, 0.1 \mathrm{CaCl}_{2}, 1$ EGTA, 10 HEPES-Cs, $0.4 \mathrm{Na}$-GTP, and 4 Na-ATP, $\mathrm{pH}$ 7.3. In experiments designed to establish the $\mathrm{Cl}^{-}$ selectivity of agonist-induced currents, an internal solution with low $\mathrm{Cl}^{-}$ concentration, close to physiological levels, was used. This solution contained (in mM): $150 \mathrm{Cs}$ gluconate, $4.6 \mathrm{MgCl}_{2}, 0.1 \mathrm{CaCl}_{2}, 1$ EGTA, 10
HEPES-Cs, $0.4 \mathrm{Na}-\mathrm{GTP}$, and $4 \mathrm{Na}-\mathrm{ATP}$. In some experiments a solution equivalent to $\mathrm{S} 1$, but with $\mathrm{K}^{+}$replacing $\mathrm{Cs}^{+}$as the main cation, was used. Neurobiotin $2 \mathrm{mg} / \mathrm{ml}$ was included in the recording pipettes.

Bicuculline methochloride, GABA, glycine, and 6-cyano-7nitroquinoxaline-2,3-dione (CNQX) were purchased from Tocris Neuramin (Bristol, UK), SR95531 from Research Biochemicals (RBI; Natick, MA), and all other chemicals from Sigma (Deisenhofen, Germany). Drug stocks were prepared as follows: $10 \mathrm{~mm}$ GABA, $10 \mathrm{~mm}$ glycine, $2 \mathrm{~mm}$ strychnine, and $10 \mathrm{~mm}$ bicuculline prepared in $\mathrm{H}_{2} 0$. CNQX and NBQX were prepared in $1 \mathrm{~mm} \mathrm{NaOH}$. Tetrodotoxin (TTX) was purchased in $1 \mathrm{mg}$ aliquots containing $5 \mathrm{mg}$ of citrate buffer, and the stock was prepared in $\mathrm{H}_{2} \mathrm{O}$ at $0.2 \mathrm{~mm}$. Stocks were aliquoted, frozen, and dissolved daily in BBS to reach the desired concentration.

Agonist-induced currents were elicited either by bath perfusion or by local application through a puffer pipette connected to a Picospritzer. In the latter case, pipettes with $\sim 5 \mu \mathrm{m}$ tip diameter were positioned at 25 $\mu \mathrm{m}$ from the recorded cell. These pipettes were filled with $20 \mu \mathrm{l}$ of a HEPES saline solution [(in mM) $145 \mathrm{NaCl}, 2.5 \mathrm{KCl}, 2 \mathrm{CaCl}_{2}, 1 \mathrm{MgCl}_{2}$, 10 HEPES-Na, pH 7.3] containing the agonists at the indicated concentration.

Histology. After electrophysiological recordings, the patch pipette was removed carefully to preserve the structure of the cell, and the slice was processed for histological examination, following the procedure described by Horikawa and Armstrong (1988). Briefly, slices were fixed overnight at $4^{\circ} \mathrm{C}$ in a $0.1 \mathrm{M}$ PBS, $\mathrm{pH} 7.4$, containing $4 \%$ paraformaldehyde. After a thorough rinsing in PBS, endogenous peroxidases were quenched in a solution containing $1 \% \mathrm{H}_{2} \mathrm{O}_{2}, 10 \%$ absolute methanol, and $89 \%$ PBS. Then the slices were incubated for $2 \mathrm{hr}$ in avidin-biotinhorseradish peroxidase complex (ABC; Vector Labs, Burlingame, $\mathrm{CA}$ ) in PBS containing $0.4 \%$ Triton X-100. The slices were rinsed in PBS and then reacted in a solution containing $0.05 \%$ diaminobenzidine and $0.15 \%$ nickel ammonium sulfate for $30 \mathrm{~min} ; 0.03 \% \mathrm{H}_{2} \mathrm{O}_{2}$ was added for the last $5 \mathrm{~min}$ of the incubation. Then the slices were mounted in a $10-90 \%$ solution of glycerol-PBS and sodium amide. The coverslips were sealed with fingernail polish for storage. Mounts were examined with a $100 \times$ oil immersion lens.

\section{RESULTS}

\section{Identification and membrane properties of RGCs}

In this study RGCs were selected on the basis of their size and location. The soma of the cells studied $(12-20 \mu \mathrm{M})$ were the largest of the ganglion cell layer (GCL) and were located in the proximal border of this layer, next to the vitreal surface. Their identification as RGCs was confirmed by histological examination after biocytin staining of the recorded cells (see Materials and Methods). The pattern of the dendritic arborization was variable, but the dendrites always projected to the inner plexiform layer; in some cases it was possible to visualize the axon running in the most external border of the GCL (data not shown).

RGCs were characterized by spontaneous action potential firing, routinely recorded in the cell-attached configuration, and by prominent voltage-gated currents observed under wcr. The latter consisted of a fast inactivating inward current caused by $\mathrm{Na}^{+}$ channel activity, as it was blocked by addition of TTX $(0.4 \mu \mathrm{M})$, followed by a noninactivating voltage-dependent outward current associated with the opening of voltage-gated $\mathrm{K}^{+}$channels. A small slow inward current persisted in TTX and was suppressed by the removal of external $\mathrm{Ca}^{2+}$ from the bathing solution (data not shown). The average density of the peak $\mathrm{Na}^{+}$current in 28 cells ranged from 20 to $1650 \mathrm{pA} / \mathrm{pF}$ (mean $\pm \mathrm{SEM}=393 \pm 86$ $\mathrm{pA} / \mathrm{pF}$ ).

\section{Synaptic input to retinal RGCs}

Synaptic currents recorded from different RGCs of light-adapted slices corresponded either to EPSCs, which could be blocked by the AMPA receptor antagonists CNQX and NBQX, or to IPSCs, the amplitude of which was unaffected by these blockers. Excitatory and inhibitory events could be distinguished unambig- 
uously by their characteristic kinetic parameters, because the former decayed within 1-2 msec whereas IPSCs had considerably longer decays (see Fig. 4). EPSCs have been observed in salamander RGCs, albeit with slower decay time course $\left(\tau_{\text {decay }}\right.$ $\sim 3.8$ msec; Taylor et al., 1995). In this paper we have used the difference in decay kinetics to distinguish the inhibitory from the excitatory synaptic events, thus avoiding the use of glutamatergic antagonists, which in preliminary experiments (results not shown) were observed to induce changes in IPSC frequency, probably by affecting retinal circuits.

A survey of the inhibitory synaptic events recorded in different RGCs revealed that they were heterogeneous and belonged to two different classes: GABAergic and glycinergic. The occurrence of these classes of IPSCs varied from cell to cell. From 37 RGCs analyzed in this study, the majority (25 cells) showed exclusively GABAergic IPSCs, six cells presented only glycinergic IPSCs, and the remaining six cells received mixed GABAergic and glycinergic inputs.

\section{GABAergic IPSCs}

Figure $1 A$ illustrates an example of the IPSCs observed in the majority of RGCs from a continuous wcr in a ganglion cell held at $-60 \mathrm{mV}$ in symmetrical $\mathrm{Cl}^{-}$conditions. In this recording, as in the majority of RGCs studied, inward current transients, the amplitude of which ranged from a few picoamps up to $>150 \mathrm{pA}$, appeared with low frequency at random. Bath application of SR95531 (3 $\mu \mathrm{M})$, a specific $\mathrm{GABA}_{\mathrm{A}}$ antagonist, blocked the IPSCs, and this effect was partially reversible. To quantify the effects of GABA and glycine receptors antagonists, we analyzed experiments in terms of the overall synaptic activity, measured as the sum of the amplitudes of all synaptic events during intervals of $20 \mathrm{sec}$, as shown in Figure $1 B$. Then the percentage of block by a given antagonist was calculated from the ratio of the mean current $/ 20 \mathrm{sec}$ in the test period over that in control condition. Using this protocol, we determined that $3 \mu \mathrm{M}$ SR95531 blocked $96.6 \pm 2.8 \%$ of the IPSCs $(n=4)$, whereas bicuculline $(3 \mu \mathrm{M})$ induced a $95.6 \pm 1.4 \%$ block of the IPSCs $(n=4)$. Pooled data are shown in Figure $5 B$.

\section{Effect of tetrodotoxin and $\mathrm{Ca}^{2+}$-free media on GABAergic IPSCs}

In $\mathrm{RGCs}$ recorded in symmetrical $\mathrm{Cl}^{-}$conditions and held at $-60 \mathrm{mV}$, the addition of TTX $(0.4 \mu \mathrm{M})$ to the external solution induced a marked decrease in the frequency of GABAergic synaptic events. The histograms of Figure $1 C$ present results from one of these experiments. Amplitude distributions are shown for control conditions (left) and in the presence of TTX (right). In this experiment TTX reduced IPSC frequency by $45 \%$ without significantly affecting the mean amplitude. The mean amplitude was $35 \mathrm{pA}$ in control, whereas the value in the presence of TTX was $31 \mathrm{pA}$. The lack of effect of TTX on IPSCs amplitude was confirmed by the cumulative amplitude distributions displayed in Figure $1 D$, where no significant shift is observed between the two curves. Figure $1 E$ summarizes data from a pool of 11 RGCs showing that, whereas the mean IPSC frequency in TTX amounts to less than one-half of the frequency in control saline, IPSCs amplitude for the same cells do not differ significantly in the two conditions.

Next, the sensitivity of TTX-resistant IPSCs to external $\mathrm{Ca}^{2+}$ ions was investigated. In two RGCs $\mathrm{Ca}^{2+}$ was removed while keeping the $\mathrm{Mg}^{2+}$ concentration at $1 \mathrm{~mm}$. The frequency of TTX-resistant GABAergic IPSCs was reduced by $22 \%$ in one cell and $45 \%$ in the other. In four other RGCs in which $\mathrm{Ca}^{2+}$ was removed and the concentration of $\mathrm{Mg}^{2+}$ was increased to $4 \mathrm{~mm}$, the frequency of GABAergic IPSCs was suppressed by $90.2 \pm 5 \%$.

\section{Glycinergic IPSCs}

In six of the RGCs studied, IPSCs had electrophysiological features that differed from those of GABAergic IPSCs. The two top traces of Figure $2 A$ illustrate an example of IPSCs recorded in a ganglion cell held at $-80 \mathrm{mV}$ in symmetric $\mathrm{Cl}^{-}$conditions. These IPSCs had a fast rising phase, but their time course of decay was slower than that of GABAergic IPSCs (see comparison in Fig. 4). Moreover, the decay phase showed discrete current steps because of the closing and opening of single ionic channels. Current fluctuations persisted for some time after the macroscopic current had reached a level close to baseline and corresponded to openings and closings of single glycine-gated channels. The bottom trace in Figure $2 A$ shows a segment of the middle trace at higher time resolution and increased magnification.

The histogram of Figure $2 B$ illustrates the amplitude distribution of IPSCs for the same RGC as in Figure $2 A$. The analysis of these IPSCs was performed by setting the detection threshold at $15 \mathrm{pA}$ to exclude single-channel events. The amplitude distribution presents a single peak with a mean amplitude of $80 \mathrm{pA}$ that, on the basis of the elementary current of the predominant single channels, would correspond to the opening of $\sim 16-18$ single transmitter-gated channels. In five cells studied, the mean amplitude of IPSCs identified as glycinergic on the basis of pharmacological criteria (see below) was $36.11 \pm 9.23 \mathrm{pA}$, whereas their frequency was $0.73 \pm 0.14 \mathrm{~Hz}$.

The elementary conductance of the glycine-gated receptorchannel complex was estimated in symmetrical chloride solutions by analyzing (1) the discrete events present in the falling phase of IPSCs (two cells) and (2) the single-channel currents elicited by bath applications of glycine (two cells). A typical trace showing glycine-gated channels after a bath application of glycine in an RGC held at $-100 \mathrm{mV}$ is illustrated in Figure $2 C$ (top trace). The left lower panel shows an all-point histogram for this experiment characterized by a multimodal distribution with a peak at $0 \mathrm{pA}$, representing the closed state, and two equally separated peaks corresponding to two channels with the same mean elementary current. The right lower panel displays the $I-V$ relation for this experiment, which has a slope conductance of $55 \mathrm{pS}$. In the four cells analyzed, the mean slope conductance was $54 \pm 2.4 \mathrm{pS}(n=4)$.

The experiments of Figure $2 D$ demonstrate the glycinergic nature of these IPSCs. The plots present the sum of the amplitudes of IPSCs recorded during sample intervals of $20 \mathrm{sec}$ against the time of recording in control saline (Fig. 2Da) and under the effect of several drugs. The application of SR95531 (3 $\mu \mathrm{M})$ induced only a very weak diminution of IPSCs activity (Fig. 2Db), whereas the presence of the classic glycinergic antagonist strychnine $(0.3 \mu \mathrm{M})$ in the saline elicited a remarkable depression of the IPSCs (Fig. 2Dc); increasing the strychnine concentration to 2 $\mu \mathrm{M}$ abolished the IPSCs (Fig. $2 D d$ ). It can be concluded from these experiments that the second class of IPSCs is mediated by glycine. In four cells strychnine $(0.3 \mu \mathrm{M})$ blocked the IPSCs by $94.6 \pm 3.6 \%$ (pooled data are shown in Fig. $5 B$ ). In one of the cells a dose-response curve for the block of IPSCs by strychnine was performed, yielding an $\mathrm{IC}_{50}$ of $22 \mathrm{~nm}$ (data not shown). 

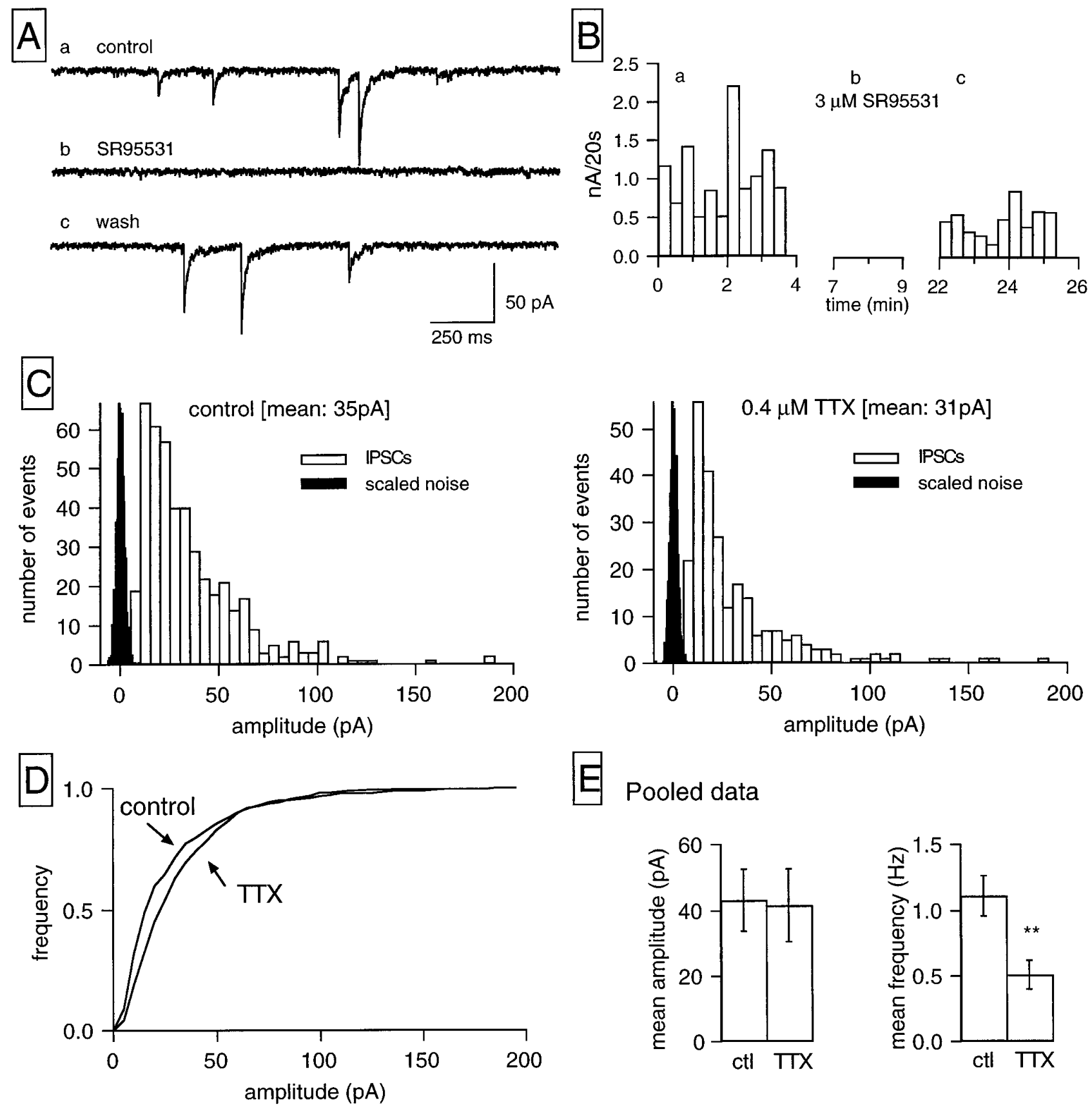

E Pooled data
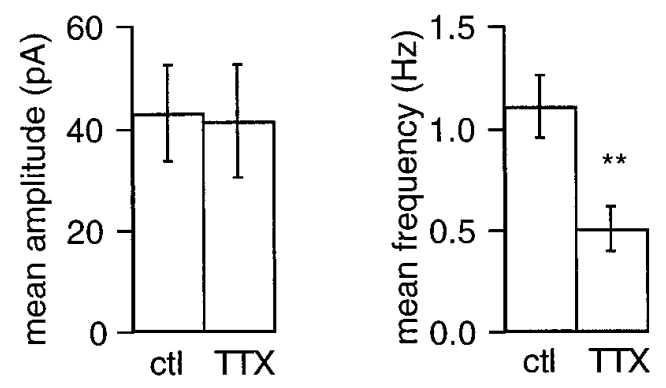

Figure 1. GABAergic IPSCs in RGCs. $A$, Selected traces from a continuous current recording obtained in symmetrical $\mathrm{Cl}^{-}$conditions. Holding potential, $-60 \mathrm{mV}$. The inward current transients present in $a$, corresponding to IPSCs, are reversibly blocked by bath application of $3 \mu \mathrm{M}$ SR 95531 (b), a blocker of GABA receptors. $B$, Plot of the sum of the amplitudes of all synaptic events detected during 20 sec intervals against time for the cell shown in $A$ in control saline $(a)$, in the presence of $3 \mu \mathrm{M}$ SR95531 $(b)$, and after removal of the antagonist $(c)$. In this and subsequent figures presenting plots of synaptic activity per unit of time, the gaps in the time axes correspond to periods in which data acquisition was interrupted, allowing for complete equilibration of the drug tested (see Materials and Methods). C, Amplitude distributions of the IPSCs recorded at $-60 \mathrm{mV}$ in control condition (left) and in the presence of $0.4 \mu \mathrm{M}$ TTX (right). The corresponding scaled noise distributions (1000 events each) are displayed in black; bin widths: 5 pA for the IPSCs, $0.5 \mathrm{pA}$ for the scaled noise histogram. The total sampling time was the same for both IPSC histograms (4 min). TTX decreased IPSC frequency without affecting their mean amplitude; the mean IPSC amplitude is $35 \mathrm{pA}$ in the control histogram (450 events, corresponding to a frequency of $1.87 \mathrm{~Hz}$ ) and $31 \mathrm{pA}$ in the TTX histogram (244 events, corresponding to a frequency of $1.02 \mathrm{~Hz}) . D$, The cumulative amplitude distributions for the same experiment are displayed. E, Data pooled from 11 cells on the effects of TTX on mean amplitude (left) and mean frequency (right) of GABAergic IPSCs recorded at $-60 \mathrm{mV}$. The vertical lines correspond to the SEM; asterisks indicate that the two groups are statistically different at the 0.001 level (Student's $t$ test).

\section{Effect of TTX and removal of external $\mathrm{Ca}^{2+}$ on glycinergic IPSCs}

Figure 3 illustrates one of the experiments performed in two different RGCs in which the effects of TTX $(0.4 \mu \mathrm{M})$ on the amplitude and frequency of glycinergic IPSCs were analyzed. The histograms plot the mean amplitude (top panels) and mean frequency (bottom panels) of the glycinergic IPSCs for $20 \mathrm{sec}$ periods against the whole-cell recording time. Figure 3, $A a$ and 

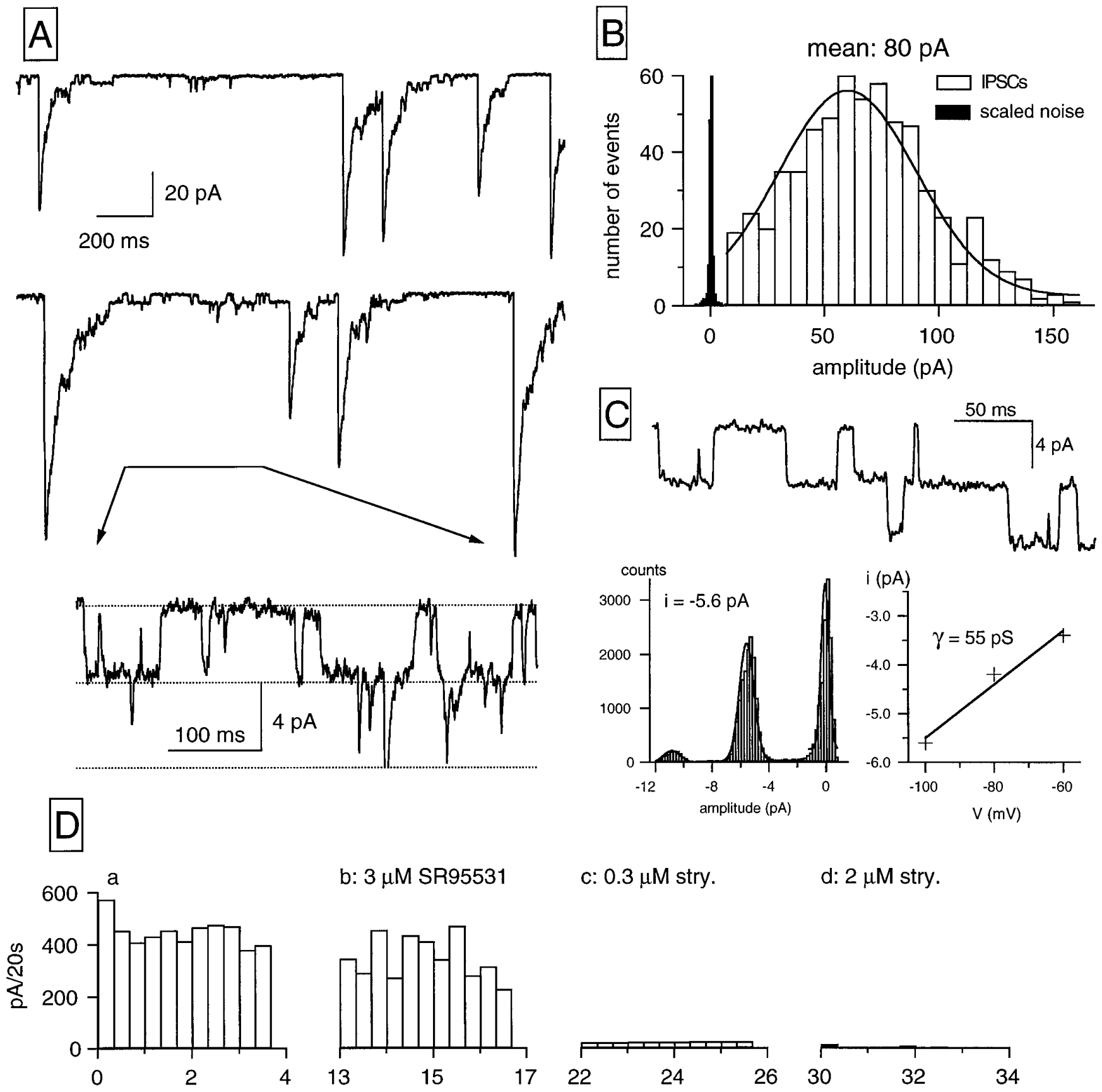

b: $3 \mu \mathrm{M}$ SR95531

c: $0.3 \mu \mathrm{M}$ stry.

$\mathrm{d}: 2 \mu \mathrm{M}$ stry.

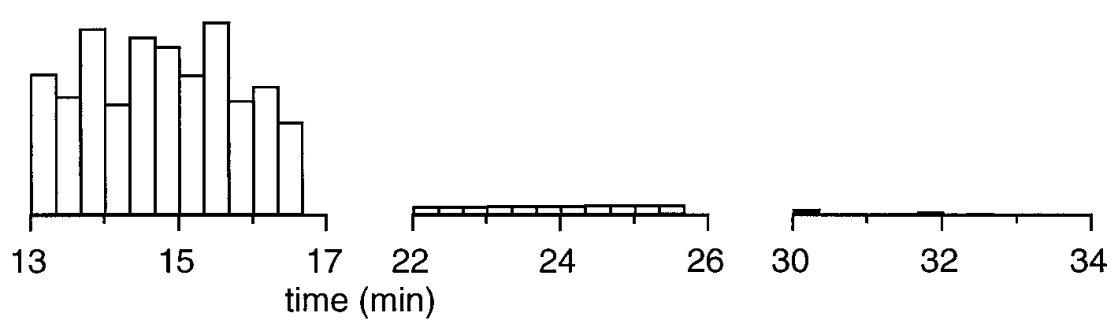

Figure 2. Glycinergic IPSCs and single-channel events in RGCs. $A$, Representative traces of glycinergic IPSCs recorded at $-80 \mathrm{mV}$ under symmetrical $\mathrm{Cl}^{-}$conditions. The inset in the lowest panel displays at an expanded time scale a section on the decay phase of an IPSC in which discrete current fluctuations, corresponding to the opening and closing of single channels, are clearly detected. The predominant amplitude of the elementary currents was $\sim 4-5 \mathrm{pA}$ at $-80 \mathrm{mV}$, corresponding to a single-channel conductance of $\sim 50 \mathrm{pS}$. $B$, Display of the IPSCs amplitude distribution for the same cell. The IPSC histogram (bin width, $7 \mathrm{pA}$ ) contains 638 events, with a mean amplitude of $80 \mathrm{pA}$. The solid line corresponds to the fit of the data by a single gaussian function; fit parameters were a mean of $60 \mathrm{pA}$ and SD of $30 \mathrm{pA}$. A relatively high detection threshold (15 pA) was used in the analysis to avoid including single-channel events. The scaled noise distribution (1000 events; bin width, $0.7 \mathrm{pA})$ is displayed in black. C, The upper panel shows single-channel events elicited at $-100 \mathrm{mV}$ by bath-applied glycine $(50 \mu \mathrm{M})$. The left plot in the lower panel illustrates an all-point histogram from the same experiment in which two channels with the same elementary current can be identified ( $6 \mathrm{sec}$ recording; bin width, $0.2 \mathrm{pA}$; the leak current has been subtracted for clarity). The solid lines correspond to the fit of the data by three gaussian functions; fit parameters (mean $\pm \mathrm{SD}$, in $\mathrm{pA}$ ) for each gaussian were $0.02 \pm 0.04,-5.5 \pm 0.7$, and $-10.8 \pm 0.9$. The right lower panel displays the $I-V$ relation for the elementary glycine-activated current determined from all-point histograms at three different membrane potentials; the solid line corresponds to the fit of the data by a linear function, yielding an estimated single-channel conductance of $55 \mathrm{pS}$. $D$, Glycinergic synaptic activity is displayed as the sum of the amplitudes of all IPSCs detected during 20 sec intervals as a function of time. The addition of the $\mathrm{GABA}_{\mathrm{A}}$ antagonist SR95531 (b) did not affect synaptic activity, whereas strychnine at $0.3 \mu \mathrm{M}(c)$ exerted a profound block on IPSCs and eliminated synaptic activity at $2 \mu \mathrm{M}(d)$. Holding potential, $-60 \mathrm{mV}$. 

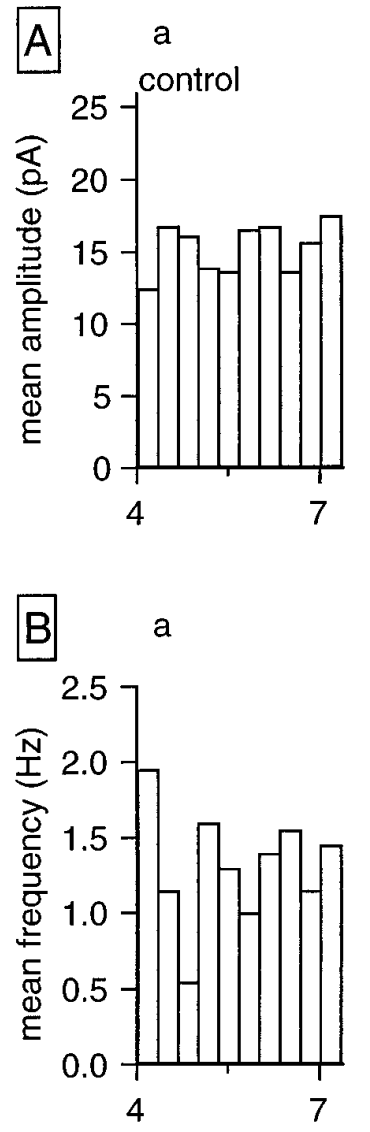

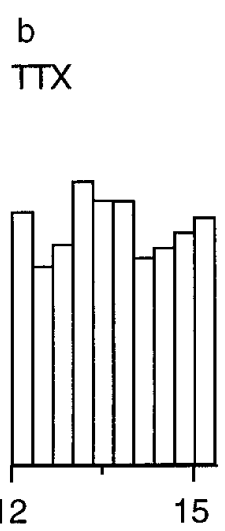

b

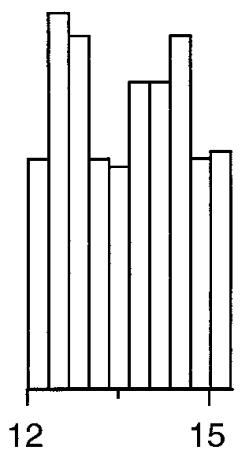

c

OCa, 2Mg, TTX TTX

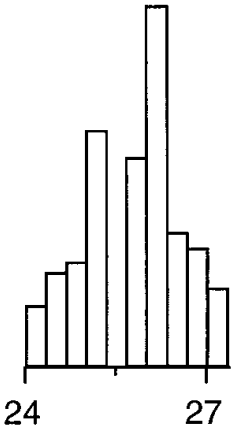

C

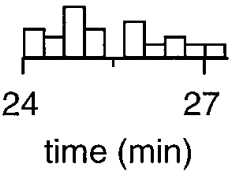

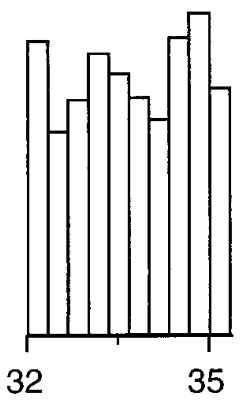

d

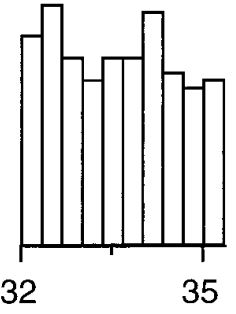

e

$3 \mu \mathrm{M}$ SR95531

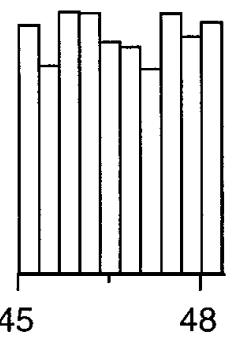

e

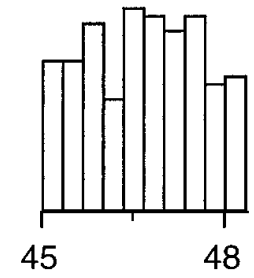

$f$

$0.3 \mu \mathrm{M}$ stry.

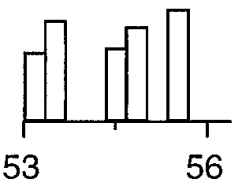

f

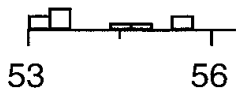

Figure 3. Lack of effect of TTX on glycinergic IPSCs. Shown are plots of the mean amplitude $(A)$ and mean frequency $(B)$ of glycinergic IPSCs detected during $20 \mathrm{sec}$ sample intervals against time in whole-cell recording. Neither the amplitude nor the frequency was affected by the addition of TTX $(0.4 \mu \mathrm{M})$ to the bathing solution ( panels $b$ ). However, removal of external $\mathrm{Ca}^{2+}$ led to a drastic reversible reduction in IPSC frequency ( panels $c, d$ ). The glycinergic nature of the IPSCs was confirmed by the lack of effect of SR95531 (panels $e$ ) and the block by a low concentration of strychnine (panels $f$ ).

$B a$, corresponds to the measurements of these parameters when the cell was bathed in normal saline. The addition of TTX affected neither the mean IPSC amplitude (Fig. 3Ab) nor the mean frequency (Fig. $3 B b$ ). In contrast, removing $\mathrm{Ca}^{2+}$ from the extracellular medium in the presence of TTX and of $2 \mathrm{mM} \mathrm{Mg}^{2+}$ reduced the mean IPSC frequency by $90 \%$ (Fig. 3Bc). $\mathrm{Ca}^{2+}$ removal did not change significantly the mean amplitude (Fig. $3 A c$ ). The irregular pattern in Figure $3 A c$ is attributable to the small sample number in each $20 \mathrm{sec}$ bin. The initial values for mean IPSC amplitude and frequency were restored when the normal $\mathrm{Ca}^{2+}$ concentration was reestablished in the TTXcontaining saline (Fig. $3 A d, B d$ ). The application of SR95531 did not affect the TTX-treated IPSCs (Fig. 3Ae,Be) whereas, as expected, $0.3 \mu \mathrm{M}$ strychnine markedly reduced both the mean amplitude and frequency of the TTX-treated glycinergic IPSCs (Fig. $3 A f, B f$ ). The same pattern of behavior was observed in the other ganglion cell tested.

In two other experiments conducted in the presence of TTX, all $\mathrm{Ca}^{2+}$ was removed from the extracellular medium while $4 \mathrm{~mm}$ $\mathrm{Mg}^{2+}$ was added. TTX-resistant glycinergic IPSCs were blocked by $85 \%$ in one of these RGCs and by $100 \%$ in the other.

\section{Time course of synaptic currents}

Besides their distinct pharmacological profile and different sensitivity to TTX, GABAergic and glycinergic IPSCs were distin- guished easily by their kinetics properties. In RGCs of slices bathed in control saline and recorded with $\mathrm{CsCl}$-filled pipettes, the GABAergic IPSCs showed a characteristic time course exemplified by the average of 73 traces, shown in Figure $4 A$. The 10 -to- $90 \%$ rise time of the averaged IPSC in this case was 0.86 msec, whereas its decay phase was best approximated by two exponentials with time constants of $8.9\left(\tau_{1}\right)$ and $34.5\left(\tau_{2}\right) \mathrm{msec}$ [the ratio of their amplitude coefficients (A2/A2 + A1) being 0.42]. Similar features were found in the eight RGCs receiving GABAergic input, which were analyzed in a similar manner with average values for the 10 -to-90\% rise time of $1.11 \pm 0.2 ; 6.52 \pm$ $1.13 \mathrm{msec}$ for $\tau_{1}$ and $40.3 \pm 3.34 \mathrm{msec}$ for $\tau_{2}$, the ratio between the amplitude coefficients being $0.67 \pm 0.06$. In the presence of TTX, GABAergic IPSCs showed kinetics indistinguishable from those in control saline; 10 -to- $90 \%$ rise time was $0.93 \pm 0.2 \mathrm{msec}$, and biexponential decays had time constants of $\tau_{1}, 7 \pm 0.6 \mathrm{msec}$ and $\tau_{2}, 40.4 \pm 8.3 \mathrm{msec}(n=4)$.

Glycinergic IPSCs were characterized by much slower decays, as illustrated by the example in Figure $4 B$, which shows the average of 182 glycinergic IPSCs. The 10 -to- $90 \%$ rise time of this averaged IPSC was $0.89 \mathrm{msec}$, and the decay phase could be approximated by two exponentials with values for $\tau_{1}$ and $\tau_{2}$ of 20 and $80 \mathrm{msec}$, respectively (the ratio between the amplitude coefficients was 0.53 ). In contrast to the GABAergic IPSCs, in this 
A Averaged GABAergic IPSC

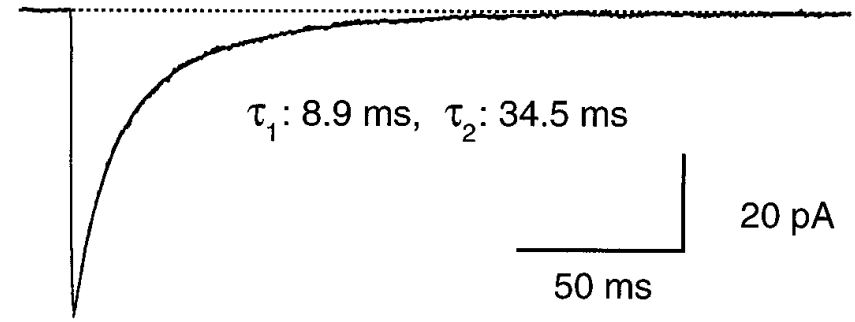

B Averaged glycinergic IPSC

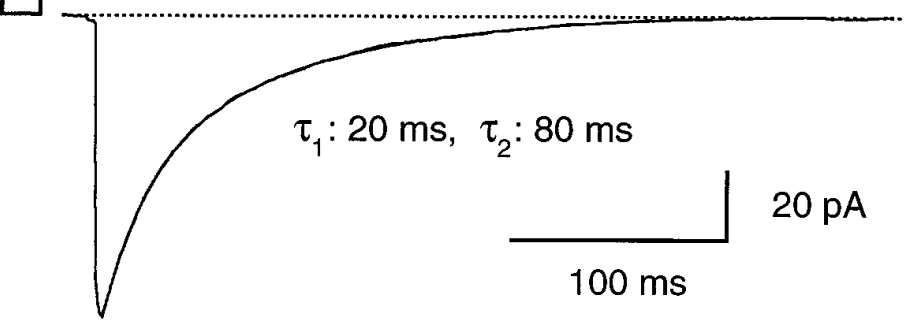

C Averaged glutamatergic EPSC

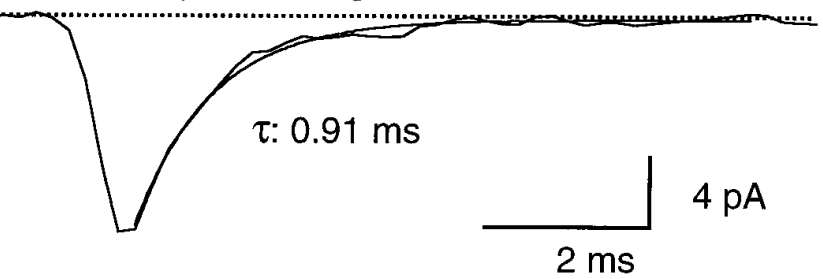

Figure 4. Comparative kinetics of GABAergic IPSCs, glycinergic IPSCs, and glutamatergic EPSCs. $A$, Average of 73 GABAergic IPSCs. Only those IPSCs separated from other IPSCs by $>150 \mathrm{msec}$ were included in the average. The decay phase was fit by the sum of two exponential functions with time constants of 8.9 and $34.5 \mathrm{msec}$ (amplitude coefficients of -36 and $-24.5 \mathrm{pA}$, respectively); the fit is superimposed on the averaged trace. $B$, Average of 182 glycinergic IPSCs. Only those IPSCs separated from other IPSCs by $>500 \mathrm{msec}$ were included in the average. The decay phase was approximated by a double-exponential function with time constants of 17.6 and $79.6 \mathrm{msec}$ (amplitude coefficients, -41 and $-49 \mathrm{pA}$, respectively). The fit is superimposed on the averaged trace. $C$, Average of 33 glutamatergic EPSCs. Superimposed on the trace is the fit of the decay phase by a single exponential with a time constant of $0.91 \mathrm{msec}$. These fast EPSCs were abolished by CNQX (10 $\mu \mathrm{M}$; data not shown).

second class of IPSCs the time course parameters showed a marked diversity from cell to cell. Thus in four RGCs the 10-to90\% rise time of averaged IPSCs varied between 0.47 and 1.12 msec (mean \pm SEM, $0.78 \pm 0.14$ ), the fast component of the decay ranged from 4.8 to $65 \mathrm{msec}$ (mean $\tau_{1}, 25.2 \pm 13.68$ ), and the slow component varied between 80 and 285 msec (mean $\tau_{2}$, $147.75 \pm 46.62)$, the ratio between the amplitude coefficients, $\mathrm{A} 2 /(\mathrm{A} 2+\mathrm{A} 1)$, being $0.54 \pm 0.08$.

As mentioned before, RGCs also showed EPSCs blocked by bath application of $10 \mu \mathrm{M}$ CNQX. Their time course was drastically different from that of IPSCs, as shown by the averaged trace in Figure $5 C$. Note the difference in time scales.

\section{Comparative pharmacology of the responses induced by GABA and glycine}

With the purpose of establishing the specificity of various antagonists on RGCs of rat retinal slices, we performed a series of

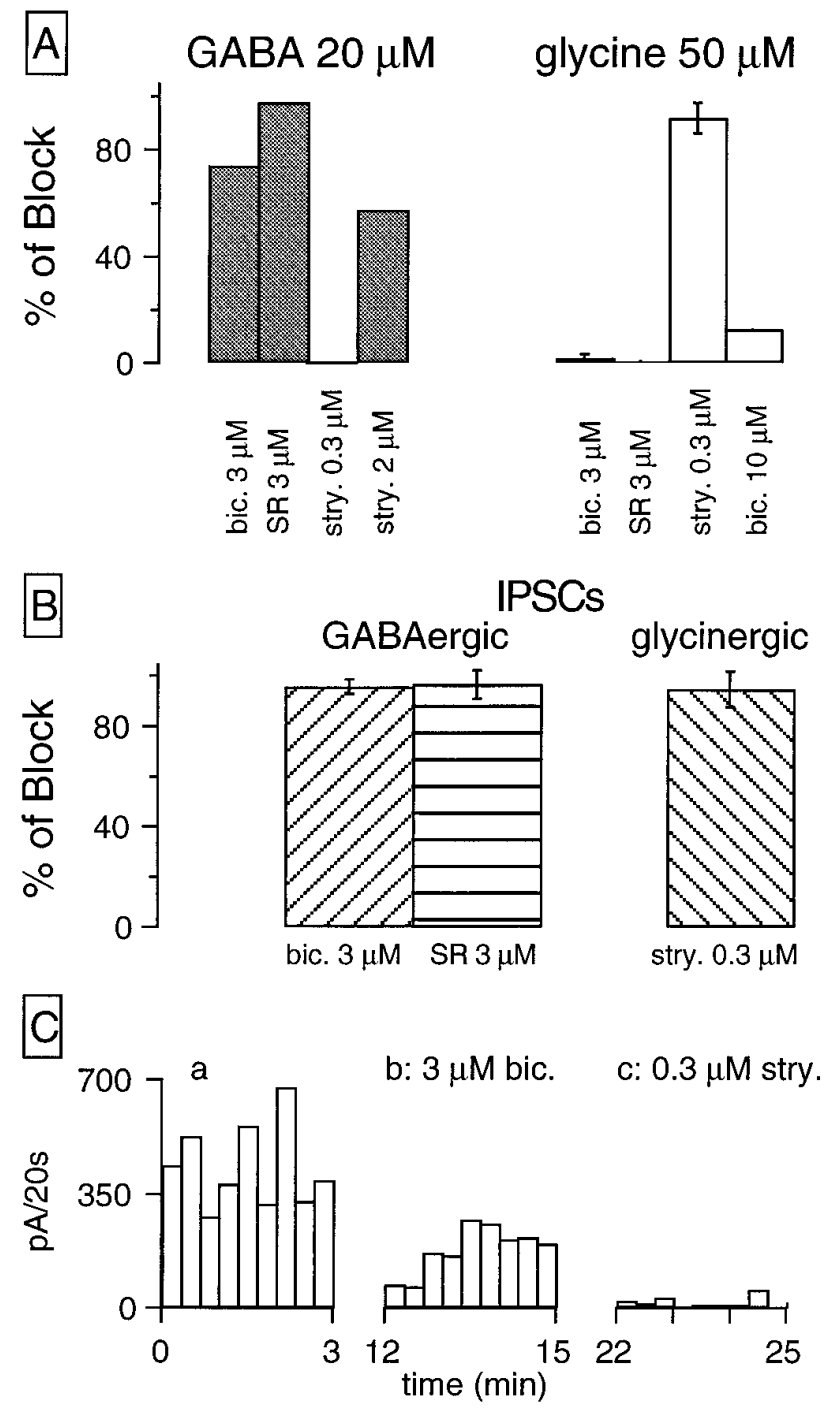

Figure 5. Pharmacological profile of agonist-induced currents and IPSCs. A, Left, The effect of various blockers on the currents induced by bath application of $20 \mu \mathrm{M}$ GABA (two cells were studied for each blocker). Right, The effects of these blockers on the currents elicited by bath application of $50 \mu \mathrm{M}$ glycine (number of cells included: three for 3 $\mu \mathrm{M}$ bicuculline, one for $3 \mu \mathrm{M}$ SR95531, four for $0.3 \mu \mathrm{M}$ strychnine, and one for $10 \mu \mathrm{M}$ bicuculline). $B$, Pooled data on the effect of various blockers on the synaptic activity, studied as the sum of all events detected per unit of time (see GABAergic IPSCs). Four cells were studied in each group. The error bars in $A$ and $B$ correspond to the SEM, calculated for groups in which $n \geq 3$. $C$, Display of the effects of bicuculline and strychnine on the IPSCs recorded from another RGC, which had a mixed population of IPSCs. Holding potential, $-60 \mathrm{mV}$. In this cell the $\mathrm{GABA}_{\mathrm{A}}$ inhibitor bicuculline produced a $40 \%$ block of IPSCs; the remaining activity was abolished by $0.3 \mu \mathrm{M}$ strychnine.

experiments in which GABA or glycine were bath-applied, and the effects of bath application of either GABA or glycine antagonists on the responses to these transmitters and on the two classes of IPSCs were compared.

The first interesting observation of these experiments performed in RGCs showing either GABAergic or glycinergic IPSCs is that all of the cells analyzed responded to the application of both transmitters independently of the nature of their synaptic input, i.e., that all RGCs were endowed with both $\mathrm{GABA}_{\mathrm{A}}$ and glycinergic receptors. Similar results were 
reported previously in cultures of mammalian RGCs (Tauck et al., 1988; Cohen et al., 1989).

The histograms in Figure 5 summarize the results of our experiments. The left panel shows that bath application of strychnine $(0.3 \mu \mathrm{M})$ does not affect at all the currents induced by bath-applied GABA $(20 \mu \mathrm{M})$, whereas when the strychnine concentration was increased to $2 \mu \mathrm{M}$, a $57 \%$ blockade of the GABAinduced currents was obtained. Bicuculline $(3 \mu \mathrm{M})$ was more effective, because it blocked GABA-induced currents by $75 \%$ whereas SR95531 (3 $\mu \mathrm{M})$ completely blocked the GABA-induced responses. The right panel of Figure $5 A$ shows the effects of antagonists on the currents induced by bath-applied glycine (50 $\mu \mathrm{M})$. These currents were blocked by $87 \%$ by a low concentration of strychnine $(0.3 \mu \mathrm{M})$ whereas SR95531 (3 $\mu \mathrm{M})$, which totally blocked the GABA-induced responses, did not affect glycineinduced currents. Bicuculline $(3 \mu \mathrm{M})$ had a very weak effect on glycine-induced currents, but when its concentration was increased to $10 \mu \mathrm{M}$, it could block these responses by $\sim 15 \%$. Figure $5 B$ shows pooled data on the effects of GABA and glycine antagonists on synaptic activity analyzed, as detailed before, in terms of the sum of IPSCs amplitude per unit of time. In view of the antagonist profile shown in Figure $5 A$, we conclude that the pharmacological criteria used in previous sections to distinguish GABAergic from glycinergic IPSCs can be applied safely in the study of RGCs inhibitory synapses.

\section{RGCs with mixed synaptic inputs}

In six RGCs the recordings showed IPSCs of both GABAergic and glycinergic nature, as evidenced by their characteristic electrophysiological features. In these six cells applications of bicuculline $(3 \mu \mathrm{M})$ and strychnine $(0.3 \mu \mathrm{M})$ helped us to ascertain the mixed nature of the synaptic input. An example is shown in Figure $5 C$ in which application of bicuculline $(3 \mu \mathrm{M})$ blocks nearly one-half of the synaptic events (Fig. $5 \mathrm{Cb})$ while strychnine $(0.3$ $\mu \mathrm{M})$ blocks the remaining IPSCs (Fig. 5Cc).

\section{Ionic selectivity of GABAergic and glycinergic receptors}

Figure 6 illustrates examples from a series of experiments in which we analyzed the $\mathrm{Cl}^{-}$dependence of the responses to local applications of GABA and glycine. In Figure $6 A 1$, in symmetrical $\mathrm{Cl}^{-}$conditions the holding potential was driven to levels ranging between -80 to $+60 \mathrm{mV}$, and GABA $(20 \mu \mathrm{M})$ was puff-applied (see Materials and Methods). The puff applications of GABA elicited inward currents at negative holding potentials, which reversed polarity at membrane potentials beyond $0 \mathrm{mV}$. As shown by the peak current-to-voltage $(I-V)$ relations in Figure $6 A 2$, GABA-induced currents presented marked voltage-dependent outward rectification, both in symmetrical $\mathrm{Cl}^{-}$solutions (open circles) or when most of the intracellular $\mathrm{Cl}^{-}$was replaced by gluconate (open triangles). Rectifying $I-V$ relations were observed in all RGCs tested with GABA puffs, as previously reported for GABA-gated $\mathrm{Cl}^{-}$channels in hippocampal neurons (Gray and Johnston, 1985) and in spinal cord neurons (Bormann et al., 1987). In five $\mathrm{RGCs}$ recorded in symmetrical $\mathrm{Cl}^{-}$conditions, currents induced by puff-applied GABA had a reversal potential of $4.8 \pm 1.8 \mathrm{mV}$, whereas in five cells studied with low intracellular $\mathrm{Cl}^{-}$, the reversal potential was $-57 \pm 1.5 \mathrm{mV}$. Both values are close to those predicted by the Nernst equation for a $\mathrm{Cl}^{-}$selective conductance. GABAergic IPSCs recorded at different membrane potentials in symmetrical $\mathrm{Cl}^{-}$(Fig. 6A3) share the main features of the agonist-induced currents, namely strong voltage-dependent outward rectification and reversal potential close to the predicted value for a $\mathrm{Cl}^{-}$-selective conductance.

Similar experiments were performed for glycinergic currents. Representative currents elicited by puffs of glycine $(50 \mu \mathrm{M})$ at different holding potentials are shown in Figure $6 B 1$ for a RGC recorded in symmetrical $\mathrm{Cl}^{-}$concentrations. In contrast to those observed for the responses to GABA, glycine-induced currents showed no voltage-dependent rectification in symmetrical $\mathrm{Cl}^{-}$ (Fig. 6B2, open circles) but had some rectification in low intracellular $\mathrm{Cl}^{-}$(Fig. 6B2, open triangles). Furthermore, the time course of recovery of the glycine-evoked currents was much slower than that of the currents induced by GABA. As in the case of responses to GABA, the $\mathrm{Cl}^{-}$selectivity of the glycine currents was confirmed by reversal potential determinations, which were $4.9 \pm$ $1.2 \mathrm{mV}(n=5)$ in symmetrical $\mathrm{Cl}^{-}$conditions and $-55.5 \pm 1.3$ $\mathrm{mV}(n=5)$ in cells dialyzed with Cs gluconate. Glycinergic IPSCs reversed close to the expected reversal potential for $\mathrm{Cl}^{-}$in symmetrical $\mathrm{Cl}^{-}$conditions, as shown by the example illustrated in Figure $6 B 3$.

\section{DISCUSSION}

\section{Differences in RGCs synaptic inputs}

The results presented here show that GABAergic and glycinergic IPSCs occur in RGCs. Nevertheless, it is not known to what extent the IPSCs observed in rat retinal slices, which are a common finding in slice preparations from different CNS regions, are attributable to the light-adapted conditions in which the experiments were performed.

The pharmacological dissection of inhibitory synaptic inputs was based on the specific block of GABAergic synaptic events by low concentrations $(3 \mu \mathrm{M})$ of SR95531 and bicuculline and of glycinergic IPSCs by $0.3 \mu \mathrm{M}$ strychnine. Actually, higher concentrations of these compounds were shown in the present experiments, as in the previous ones of Cohen et al. (1989), to affect the responses to both amino acids. A distinct class of bicucullineinsensitive GABA receptors, the $\mathrm{GABA}_{\mathrm{C}}$ receptors, is present in several retinal neurons (for review, see Bormann and Feigenspan, 1995). Enz et al. (1996) have shown that mammalian RGCs lack $\mathrm{GABA}_{\mathrm{C}} \rho$ receptor subunits. In agreement, we find that all of the GABAergic IPSCs, as well as the responses to exogenous GABA, were blocked completely by bicuculline, thus ruling out the presence of functional $\mathrm{GABA}_{\mathrm{C}}$ receptors in RGCs.

Despite the presence of receptors to both amino acids in all RGCs examined, GABAergic synapses predominate in the majority of the RGCs analyzed. The wider distribution of GABAergic inputs among RGCs in comparison with the more restricted occurrence of the glycinergic ones may arise from differences in the dendritic field of the amacrine cells involved. As previously reported (see Vaney, 1990), glycine-accumulating amacrine cells in mammalian retinas have much narrower dendritic fields than GABAergic amacrines, which generally are endowed with medium or large dendritic fields. However, RGCs are a morphologically and functionally heterogeneous population (Wässle and Boycott, 1991), and inhibitory synaptic inputs may depend on RGC subtype and on the light conditions that determine which retinal circuits are active. Because no correlation between morphological type and/or response to light stimuli with the synaptic input has been established in the present work, we cannot elucidate this point. 
A1

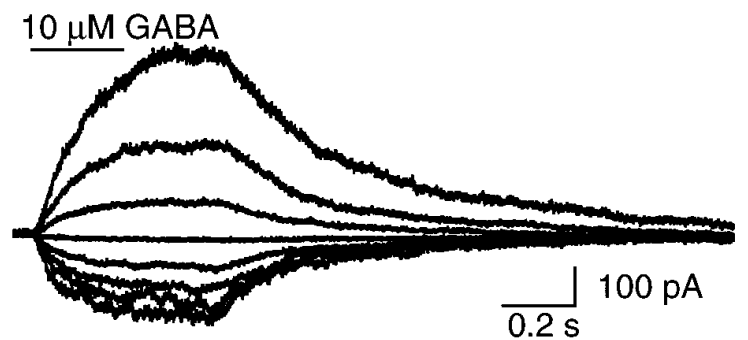

A2

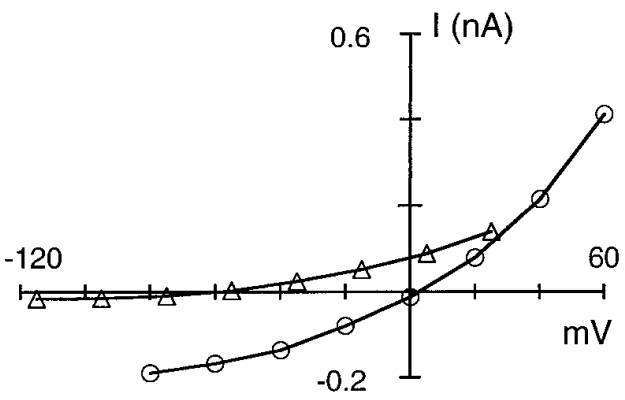

A3

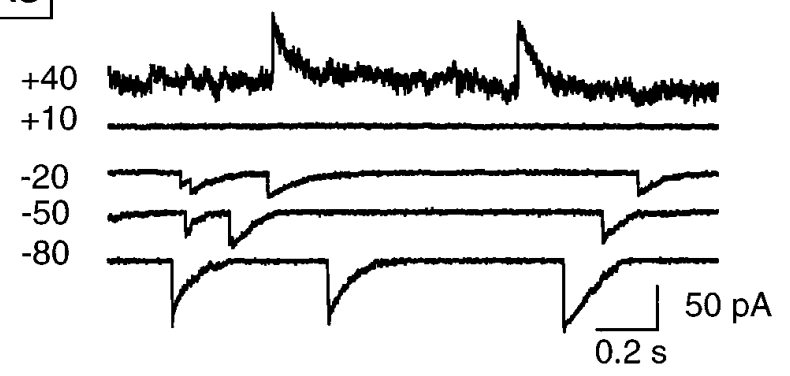

B1
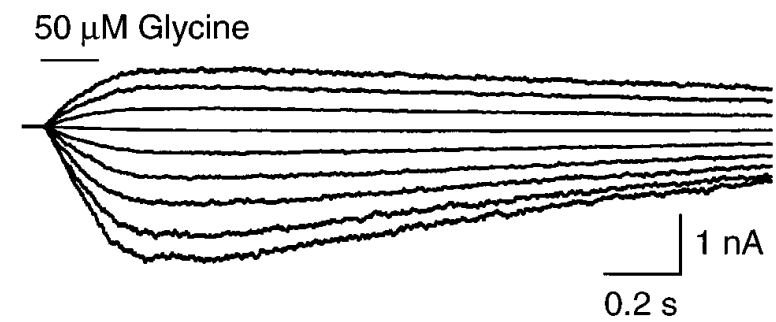

B2

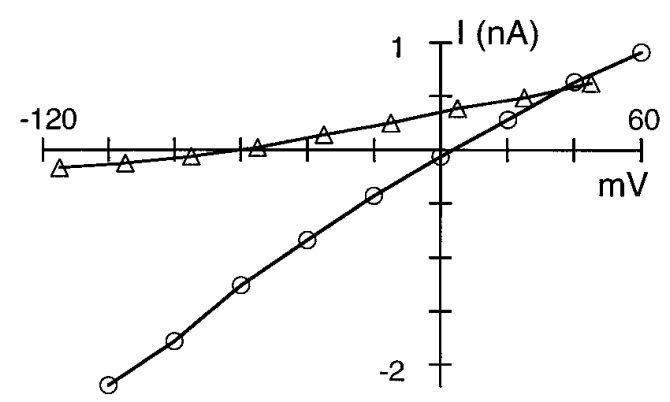

B3

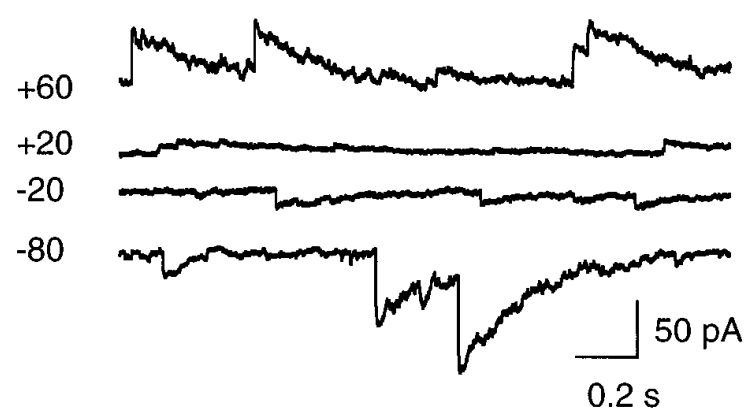

Figure 6. $\mathrm{Cl}^{-}$-selective $\mathrm{GABA}_{\mathrm{A}}$ and glycine receptors in ganglion cells. $A 1$, Current responses to $250 \mathrm{msec}$ puffs of $10 \mu \mathrm{M}$ GABA obtained in a cell dialyzed with $\mathrm{CsCl}$ at membrane potentials ranging from -80 to $+60 \mathrm{mV}$. In all of the experiments in which agonist-evoked currents were studied as a function of membrane potential, the holding potential was held at $-60 \mathrm{mV}$, changed to the desired value 2 sec before the puff application, and maintained at that level for 2 additional sec while data were acquired. The current previous to the agonist application was subtracted from the traces. $A 2$, Relation between membrane voltage and the peak of the GABA-induced current for the experiment shown in $A 1(O)$ and for a different cell dialyzed with low $\mathrm{Cl}^{-}(\triangle)$. A3, GABAergic IPSCs recorded at the membrane potentials, indicated at the left of the traces for the cell shown in $A 1$. B1, Representative responses to $150 \mathrm{msec}$ puffs of $50 \mu \mathrm{M}$ glycine obtained from a cell dialyzed with $\mathrm{CsCl}$ at membrane potentials ranging from -100 to +60 $\mathrm{mV}$. B2, The $I-V$ relation for the cell shown in $A 2(O)$ and for a different cell dialyzed with low $\mathrm{Cl}^{-}(\triangle)$. The experimental protocol was similar to that described for $A$. B3, Glycinergic IPSCs recorded in the cell shown in B1 at different holding potentials, indicated at the left of the traces.

\section{GABAergic versus glycinergic IPSCs}

There were marked differences in the properties of GABAergic and glycinergic IPSCs recorded from RGCs. The decay phase of glycinergic IPSCs, in contrast to that of GABAergic IPSCs, showed an important cell-to-cell variability. Different glycine receptor subunits (the $\alpha_{1}, \alpha_{2}, \alpha_{3}$, and $\beta$ subunits) have been detected at the rat RGC layer by both immunocytochemical and RNA hybridization techniques (Greferath et al., 1994b; Koulen et al., 1996). An unequal distribution of these subunits among RGCs could contribute to the variation in the time course of decay of the glycinergic IPSCs (see Legendre and Korn, 1994). Furthermore, the presence of visible current jumps on the decay phase, corresponding to closings of single channels, characterized glycinergic IPSCs. The single-channel conductance $(\sim 54 \mathrm{pS})$ matches that of the most frequent subconductance state found via analysis of glycinergic IPSCs in spinal cord neurons (Takahashi and Momiyama, 1991) and in cerebellar Golgi cells (Dieudonné, 1995), as well as the estimates from single-channel recordings in spinal neurons (Bormann et al., 1987) and cerebellar granule cells (Kaneda et al., 1996). Single-channel currents trailed the IPSCs. This could arise either from persistence of transmitter in the synaptic cleft or from glycine receptors undergoing reopenings after desensitization in the agonist-bound configuration, as recently proposed for $\mathrm{GABA}_{\mathrm{A}}$ receptors (Jones and Westbrook, 1995).

Despite the observed variability in their decay kinetics, glycinergic IPSCs were significantly slower than GABAergic ones. This situation differs from that found in the spinal cord, where GABAergic synaptic potentials have slower decays than glycinergic ones (Yoshimura and Nishi, 1995). In RGCs, glycinergic IPSCs decay was biexponential, the slower time constant falling 
into the hundreds of milliseconds range. This is in sharp contrast to the very fast monoexponential decay in zebra fish brain $(\tau, 4-6$ msec; Legendre and Korn, 1994). The presence of the $\alpha_{2}$ subunit in RGCs of adult rats (Koulen et al., 1996) could account for the observed prolonged decay, because this subunit confers long open times to glycine-gated currents (Takahashi et al., 1992). Furthermore, in the spinal cord a developmental shift from $\alpha_{2}$ to $\alpha_{1}$ is paralleled by a shortening of the decay of IPSCs (Takahashi et al., 1992). The high sensitivity to strychnine of RGCs glycinergic IPSCs is surprising because the $\alpha_{2}$ subunit is considered to be responsible for the relative immunity to strychnine poisoning in neonatal rats, and its disappearance during development is associated with an increase in sensitivity of the glycine receptor to this alkaloid (Kuhse et al., 1990).

The decay of GABAergic IPSCs in retinal ganglion cells was also biexponential. The observed values for the fast and slow time constants are in the same range as those for hippocampal granule cells (Edwards et al., 1990), cerebellar stellate cells (Llano and Gerschenfeld, 1993), and cerebellar granule cells (Tia et al., 1996). These values differ from those reported by Jones and Westbrook (1995) in their study of cultured hippocampal neurons, which have GABAergic IPSCs with much slower biexponential decays; the authors interpreted IPSCs decay as arising from receptor desensitization.

\section{Effects of TTX and $\mathrm{Ca}^{2+}$-free media}

Another striking difference between the two classes of IPSCs concerns their behavior in the presence of TTX. The frequency of GABAergic IPSCs was reduced markedly by TTX, whereas that of glycinergic IPSCs remained unaffected. Therefore, the release of transmitter from glycinergic amacrine cells responsible for the generation of IPSCs in our RGCs population does not depend on the activation of voltage-gated $\mathrm{Na}^{+}$channels. Although glycinergic amacrine AII cells are able to discharge $\mathrm{Na}^{+}$ action potentials, their electrotonic compactness may allow transmitter release without the requirement of action potential propagation (Boos et al., 1993). It is also evident that a fraction of the GABAergic IPSCs is generated by transmitter released via a mechanism independent of voltage-gated $\mathrm{Na}^{+}$channels. The fact that both TTX-resistant GABAergic IPSCs and all of the glycinergic IPSCs were blocked by $\mathrm{Ca}^{2+}$-free media suggests that transmitter can be released either by local depolarization inducing $\mathrm{Ca}^{2+}$ influx into amacrine cell dendrites or by $\mathrm{Ca}^{2+}$ influx at resting membrane potential. In synaptic terminals from goldfish retinal bipolar cells there is a considerable calcium influx through L-type $\mathrm{Ca}^{2+}$ channels at membrane potentials close to $-55 \mathrm{mV}$ (Kobayashi and Tachibana, 1995). A similar mechanism may operate in amacrine cells, because their resting membrane potential is close to $-60 \mathrm{mV}$ (Boos et al., 1993), and it has been shown that transmitter release at amacrine-amacrine cell synapses in culture depends on L-type $\mathrm{Ca}^{2+}$ channels (Gleason et al., 1994).

In conclusion, in our recording (light-adapted) conditions GABAergic IPSCs in RGCs can be elicited either by $\mathrm{Na}^{+}$. dependent action potentials or by local $\mathrm{Ca}^{2+}$ influx, presumably of medium or large dendritic field GABAergic amacrine cells, whereas glycinergic IPSCs are generated by depolarization inducing $\mathrm{Ca}^{2+}$ influx in narrow field glycinergic amacrine cells.

\section{REFERENCES}

Agardh EB, Bruun A, Ehinger B, Storm-Mathisen J (1986) GABA immunoreactivity in the retina. Invest Ophthalmol 27:674-678.

Boos R, Schneider H, Wässle H (1993) Voltage- and transmitter-gated currents of AII amacrine cells in a slice preparation of the rat retina. J Neurosci 13:2874-2888.

Bolz J, Frumkes T, Voigt T, Wässle H (1985a) Action and localization of $\gamma$-aminobutyric acid in the cat retina. J Physiol (Lond) 362:369-393.

Bolz J, Thier P, Voigt T, Wässle H (1985b) Action and localization of glycine and taurine in the cat retina. J Physiol (Lond) 362:395-413.

Bormann J, Feigenspan A (1995) GABA $_{c}$ receptors. Trends Neurosci 18:515-519.

Bormann J, Hamill OP, Sakmann B (1987) Mechanism of anion permeation through channels gated by glycine and $\gamma$-aminobutyric acid in mouse cultured spinal neurones. J Physiol (Lond) 385:243-286.

Brecha NC, Johnson D, Peichl L, Wässle H (1988) Cholinergic amacrine cells contain glutamate decarboxylase and gamma-aminobutyrate reactivity. Proc Natl Acad Sci USA 85:6187-6189.

Chun MH, Wässle H (1989) GABA immunoreactivity in the cat retina: electron microscopy. J Comp Neurol 279:55-67.

Cohen BN, Fain GL, Fain MJ (1989) GABA and glycine channels in isolated ganglion cells from goldfish retina. J Physiol (Lond) 417:53-82.

Davenger S, Ottersen OP, Storm-Mathisen J (1991) Glutamate, GABA, and glycine in the human retina: an immunocytochemical investigation. J Comp Neurol 311:483-494.

Dieudonné S (1995) Glycinergic synaptic currents in Golgi cells of the rat cerebellum. Proc Natl Acad Sci USA 92:1441-1445.

Edwards FA, Konnerth A, Sakmann B (1990) Quantal analysis of inhibitory synaptic transmission in the dentate gyrus of rat hippocampal slices: a patch-clamp study. J Physiol (Lond) 430:213-249.

Enz R, Brandstätter JH, Wässle H, Bormann J (1996) Immunocytochemical localization of the $\mathrm{GABA}_{\mathrm{c}}$ receptor $\rho$ subunits in the mammalian brain. J Neurosci 16:4479-4490.

Gleason E, Borges S, Wilson M (1994) Control of transmitter release from retinal amacrine cells by $\mathrm{Ca}^{2+}$ influx and efflux. Neuron 13:1109-1117.

Gray R, Johnston D (1985) Rectification of single GABA-gated chloride channels in adult hippocampal neurons. J Neurophysiol 54:134-142.

Greferath U, Grünert U, Müller F, Wässle H (1994a) Localization of $\mathrm{GABA}_{\mathrm{A}}$ receptors in the rabbit retina. Cell Tissue Res 276:295-307.

Greferath U, Brandstätter H, Wässle H, Kirsch H, Kuhse J, Grünert U (1994b) Differential expression of glycine receptor subunits in the retina of the rat: a study using immunohistochemistry and in situ hybridization. Vis Neurosci 11:721-729.

Grünert U, Wässle H (1993) Immunocytochemical localization of glycine receptors in the mammalian retina. J Comp Neurol 335:523-537.

Grünert U, Greferath U, Boycott BB, Wässle H (1993) Parasol (P $\alpha)$ ganglion cells of the primate fovea: immunocytochemical staining with antibodies against $\mathrm{GABA}_{\mathrm{A}}$ receptors. Vision Res 33:1-14.

Hamill OP, Marty A, Neher E, Sakmann B, Sigworth F (1981) Improved patch-clamp techniques for high-resolution current recording from cells and cell-free membrane patches. Pflügers Arch 391:85-100.

Hendrickson AE, Koontz MA, Pourcho RG, Sarthy PV, Goebel DJ (1988) Localization of glycine-containing neurons in the Macaca monkey retina. J Comp Neurol 273:473-487.

Horikawa K, Armstrong W (1988) A versatile means of intracellular labeling: injection of biocytin and its detection with avidin conjugates. J Neurosci Methods 25:1-11.

Hughes TE, Carey RG, Victorica J, de Blas AL, Karten H (1989) Immunochemical localization of $\mathrm{GABA}_{\mathrm{A}}$ receptors in the retina of the new world primate Saimiri sciureus. Vis Neurosci 2:565-581.

Hughes TE, Grünert U, Karten $H$ (1991) GABA $_{A}$ receptors in the retina of the cat: an immunohistochemical study of whole mounts, sections, and dissociated cells. Vis Neurosci 6:229-238.

Ishida AT (1992) The physiology of $\mathrm{GABA}_{\mathrm{A}}$ receptors. In: Progress in brain research, Vol 90 (Miz RR, Marc RE, Sillito AM, eds), pp 29-45. Amsterdam: Elsevier.

Ishida AT, Cohen BN (1988) GABA-activated whole-cell currents in isolated retina ganglion cells. J Neurophysiol 60:381-396.

Jones MV, Westbrook GL (1995) Desensitized states prolong GABA $_{\mathrm{A}}$ channel responses to brief agonist pulses. Neuron 15:181-191.

Kaneda M, Farrant M, Cull-Candy SG (1996) Whole-cell and singlechannel currents activated by GABA and glycine in granule cells of the rat cerebellum. J Physiol (Lond) 485:419-435.

Kobayashi K, Tachibana M (1995) $\mathrm{Ca}^{2+}$ regulation in the presynaptic terminals of goldfish retinal bipolar cells. J Physiol (Lond) 483:79-94.

Koontz MA, Hendrickson AE (1990) Distribution of GABA immunoreactivity amacrine cell synapses in the inner plexiform layer of macaque monkey retina. Vis Neurosci 5:17-28. 
Koontz MA, Hendrickson LE, Brace ST, Hendrickson AE (1993) Immunocytochemical localization of GABA and glycine in amacrine and displaced amacrine cells of macaque monkey retina. Vision Res 33:2617-2628.

Koulen P, Sassoé-Pognetto M, Grünert U, Wässle H (1996) Selective clustering of $\mathrm{GABA}_{\mathrm{A}}$ and glycine receptors in the mammalian retina. J Neurosci 16:2127-2140.

Kuhse J, Schmieden V, Betz H (1990) A single amino acid exchange alters the pharmacology of neonatal rat glycine receptor subunit. Neuron 5:867-873.

Legendre P, Korn H (1994) Glycinergic inhibitory synaptic currents and related receptor channels in the zebra fish brain. Eur J Neurosci 6:1544-1557.

Llano I, Gerschenfeld HM (1993) Inhibitory synaptic currents in stellate cells of rat cerebellar slices. J Physiol (Lond) 468:177-200.

Marc RE, Liu W-LS (1985) $\left[{ }^{3} \mathrm{H}\right]$ glycine-accumulating neurons of the human retina. J Comp Neurol 232:241-260.

Mosinger JL, Yazulla S (1987) Double-label analysis of GABA- and GAD-like immunoreactivity in the rabbit retina. Vision Res 27:23-30.

Mosinger JL, Yazulla S, Studholme KM (1986) GABA-like immunoreactivity in the vertebrate retina: a species comparison. Exp Eye Res 42:631-644.

Osborne NN, Patel S, Beaton DW, Neuhoff V (1986) GABA neurones in retinas of different species and their postnatal development in situ and in culture in the rabbit retina. Cell Tissue Res 243:117-123.

Pourcho RG (1980) Uptake of $\left[{ }^{3} \mathrm{H}\right]$ glycine and $\left[{ }^{3} \mathrm{H}\right] \mathrm{GABA}$ by amacrine cells in the cat retina. Brain Res 198:333-346.

Pourcho RG, Goebel DJ (1983) Neuronal subpopulations in cat retina that accumulate the GABA agonist $\left[{ }^{3} \mathrm{H}\right]$ muscimol: a combined Golgi and autoradiographic study. J Comp Neurol 219:25-35.

Pourcho RG, Owarczak MT (1991) Glycine receptor immunoreactivity is localized at amacrine synapses in cat retina. Vis Neurosci 7:611-618.

Protti DA, Gerschenfeld HM, Llano I (1996) Inhibitory synaptic currents and agonist-induced responses in ganglion cells from rat retinal slices. Soc Neurosci Abstr 22:786.

Rörig B, Grantyn R (1993) Glutamatergic and GABAergic synaptic currents in ganglion cells from isolated retinae of pigmented rats during postnatal development. Dev Brain Res 74:98-110.

Saito H (1983) Pharmacological and morphological differences between $\mathrm{X}$ - and Y-type ganglion cells in the cat's retina. Vision Res 23:1299-1308.
Sarthy PV, Fu M (1989) Localization of L-glutamic acid decarboxylase mRNA in cat retinal cells by in situ hybridization. J Comp Neurol 288:593-600.

Takahashi T, Momiyama A (1991) Single-channel currents underlying glycinergic inhibitory postsynaptic responses in spinal neurons. Neuron 7:965-969.

Takahashi T, Momiyama A, Hirai K, Hishinuma F, Akagi H (1992) Functional correlation of fetal and adult forms of glycine receptors with developmental changes in inhibitory synaptic receptor channels. Neuron 9:1155-1161.

Tauck DL, Frosch MP, Lipton SA (1988) Characterization of GABAand glycine-induced currents of solitary rodent retinal ganglion cells in culture. Neuroscience 27:193-203.

Taylor WR, Chen E, Copenhagen DR (1995) Characterization of spontaneous excitatory synaptic currents in salamander retinal ganglion cells. J Physiol (Lond) 486:207-221.

Tia S, Wang JF, Kotchabhadki N, Vicini S (1996) Developmental changes of inhibitory synaptic currents in cerebellar granule neurons: role of $\mathrm{GABA}_{\mathrm{A}}$ receptor $\alpha 6$ subunit. J Neurosci 16:3630-3640.

Vaney DI (1990) The mosaic of amacrine cells in the mammalian retina. In: Progress in retinal research, Vol 9 (Osborne NN, Chader GJ, eds), pp 49-100. Oxford: Pergamon.

Vaney DI, Young HM (1988) GABA-like reactivity in NADPHdiaphorase amacrine cells of the rat retina. Brain Res 474:380-385.

Vincent P, Marty A (1993) Neighboring cerebellar Purkinje cells communicate via retrograde inhibition of common presynaptic neurons. Neuron 11:885-893.

Wässle H, Boycott BB (1991) Functional architecture of the mammalian retina. Physiol Rev 71:447-480.

Wässle H, Chun MH (1989) GABA-like immunoreactivity in the cat retina: light microscopy. J Comp Neurol 279:43-54.

Wässle H, Chun MH, Muller F (1987) Amacrine cells in the ganglion cell layer of the retina. J Comp Neurol 265:391-408.

Yoshimura M, Nishi S (1995) Primary afferent-evoked glycine- and GABA-mediated IPSPs in substantia gelatinosa neurones in the rat spinal cord in vitro. J Physiol (Lond) 482:29-38.

Zhou ZJ, Marshak DW, Fain GL (1994) Amino acid receptors of midget and parasol ganglion cells in primate retina. Proc Natl Acad Sci USA 91:4907-4911. 